\title{
DEMOKRASI DALAM SEJARAH KETATANEGARAAN REPUBLIK INDONESIA
}

\author{
Arif Wijaya \\ Universitas Islam Negeri Sunan Ampel Surabaya | \\ rifjaya2@gmail.com
}

\begin{abstract}
; this paper highlights democracy in the history of the constitution of the Republic of Indonesia. In the history of the nation, from independence to now, there are three kinds of democracy that once applied in the constitutional life of Indonesia, namely the liberal democracy, the guided democracy, and the Pancasila democracy. The liberal democracy leads to a failure of the Constituent establishing Undang-Undang Dasar 1945 as a replacement of Undang-Undang Dasar Sementara 1950. The Guided Democracy is under the reign of the old order and the Pancasila democracy is under the rule of the new order. Although the initial concept for the period intended as an implementation of the fourth principle of Pancasila, but the power was ultimately centralized on the hand of President. A failure of the old and the new order to uphold the values of democracy cause a reformation. In this reformation era, the values of democracy are expected to be enforced.
\end{abstract}

Keywords: The liberal democracy, the guided democracy, the Pancasila democracy.

Abstrak; Dalam perjalanan sejarah bangsa, sejak kemerdekaan hingga sekarang, terdapat tiga macam demokrasi yang pernah diterapkan dalam kehidupan ketatanegaraan di Indonesia, yaitu demokrasi liberal, demokrasi terpimpin, dan demokrasi pancasila. Demokrasi liberal bermuara pada kegagalan konstituante menetapkan UUD pengganti UUDS 1950. Demokrasi terpimpin di bawah pemerintahan orde lama dan demokrasi pancasila di bawah pemerintahan orde baru. Meskipun konsep awal pada periode tersebut dimaksudkan sebagai implementasi dari sila keempat Pancasila, tetapi pada akhirnya kekuasaan terpusat pada tangan seorang Presiden. Kegagalan orde lama dan orde baru untuk menegakkan nilai-nilai demokrasi menyebabkan bergulirnya 
reformasi. Dalam era reformasi ini, diharapkan nilai-nilai demokrasi dapat ditegakkan.

Kata Kunci: Demokrasi liberal, Demokrasi terpimpin, Demokrasi pancasila.

\section{Pendahuluan}

Demokrasi di Indonesia melewati sejarah yang panjang. Usaha untuk mewujudkan pemerintahan demokratis dapat dilihat dari rumusan model demokrasi Indonesia di dua zaman pemerintahan Indonesia, yakni orde lama dan orde baru. Pada era Soekarno dikenalkan model demokrasi terpimpin, sedangkan era Soeharto dimunculkan demokrasi pancasila. Namun model demokrasi yang ditawarkan di dua rezim tesebut malah memunculkan pemerintahan otoritarian, yang membelenggu kebebasan politik warganya.

Di era yang disebut demokrasi pancasila justru terjadi pelanggaran HAM selama usia kekuasaan itu. Sila "kemanusiaan yang adil dan beradab" adalah sila yang dikhianati karena pelanggaran HAM dilakukan sedemikian rupa secara harfiah. Penangkapan, penahanan, dan penghilangan aktivis atau tokoh kritis secara paksa, pembredelan media cetak, penembakan tanpa alasan dan proses hukum yang dikenal dengan penembakan misterius (petrus), pembantaian warga sipil di Talangsari Lampung, Sindang Raya Tanjung Priok, Kedung Ombo, Operasi Militer di Aceh, Papua dan seterusnya adalah contoh kejahatan kemanusiaan rezim Soeharto.

Dipasung dan dirampasnya HAM serta matinya demokrasi di era orde baru itu secara perlahan membuat kekuatan-kekuatan strategis rakyat, mahasiswa, pers, lembaga swadaya masyarakat (LSM), tokoh-tokoh partai politik yang terpinggirkan serta kaum intelektual kampus bersatu menjadi kekuatan besar menyuarakan reformasi politik setelah Soeharto memangku jabatan sebagai presiden untuk ketujuh kalinya pada tahun 1997.

Perilaku korupsi, kolusi dan nepotisme (KKN) orde baru yang memuncak di tahun 1997 tersebut, ditambah pula dengan krisis 
ekonomi dan perpecahan di tubuh militer dan Golkar sebagai penyangga utama rezim Soeharto, menjadi faktor situasional dan pencetus jatuhnya rezim Soeharto pada 21 Mei 1998. Kejatuhan rezim otoriter yang berkuasa selama 32 tahun itu menjadi titik berangkat transisi politik menuju demokrasi di Indonesia. ${ }^{1}$ Semenjak itu berlaku demokrasi pada pasca orde aru dan demokrasi pada era reformasi.

\section{Sejarah Demokrasi di Indonesia}

Sejak Indonesia merdeka dan berdaulat sebagai sebuah negara pada tanggal 17 Agustus 1945, para Pendiri Negara Indonesia (the Founding Fathers) melalui UUD 1945 (yang disahkan pada tanggal 18 Agustus 1945) telah menetapkan bahwa Negara Kesatuan Republik Indonesia menganut paham atau ajaran demokrasi, dimana kedaulatan (kekuasaan tertinggi) berada ditangan Rakyat dan dilaksanakan sepenuhnya oleh Majelis Permusyawaratan Rakyat (MPR). Dengan demikian berarti juga NKRI tergolong sebagai negara yang menganut paham Demokrasi Perwakilan (Representative Democracy). ${ }^{2}$

\section{Pelaksanaan Demokrasi Masa Revolusi (1945-1950)}

Tahun 1945 - 1950, Indonesia masih berjuang menghadapi Belanda yang ingin kembali ke Indonesia. Pada saat itu pelaksanaan demokrasi belum berjalan dengan baik. Hal itu disebabkan oleh masih adanya revolusi fisik. Pada awal kemerdekaan masih terdapat sentralisasi kekuasaan hal itu terlihat Pasal 4 Aturan Peralihan UUD 1945 yang berbunyi sebelum MPR, DPR dan DPA dibentuk menurut UUD ini segala kekuasaan dijalankan oleh Presiden dengan dibantu oleh KNIP. Untuk menghindari kesan bahwa negara Indonesia adalah negara yang absolut pemerintah mengeluarkan:

Suparman Marzuki, Politik Hukum: Hak Asasi Manusia, (Jakarta: Penerbit Erlangga, 20 I4), 25.

http://hilalfarisy.wordpress.com/2012/03/2 I/sejarah-perkembangan-demokrasi-di-indonesia, diakses 6 Maret 2014. 
a. Maklumat Wakil Presiden No. X tanggal 16 Oktober 1945, KNIP berubah menjadi lembaga legislatif.

b. Maklumat Pemerintah tanggal 3 Nopember 1945 tentang Pembentukan Partai Politik.

c. Maklumat Pemerintah tanggal 14 Nopember 1945 tentang perubahan sistem pemerintahn presidensil menjadi parlementer.

\section{Pelaksanaan Demokrasi Masa Orde Lama (1950-1965)}

1. Masa Demokrasi Liberal (1950-1959)

Pelaksanaan demokrasi liberal sesuai dengan konstitusi yang berlaku saat itu, yakni Undang Undang Dasar Sementara 1950. Kondisi ini bahkan sudah dirintis sejak dikeluarkannya maklumat pemerintah tanggal 16 Oktober 1945 dan maklumat tanggal 3 November 1945, tetapi kemudian terbukti bahwa demokrasi liberal atau parlementer yang meniru sistem Eropa Barat kurang sesuai diterapkan di Indonesia. Tahun 1950 sampai 1959 merupakan masa berkiprahnya parta-partai politik. Dua partai terkuat pada masa itu (PNI \& Masyumi) silih berganti memimpin kabinet. Sering bergantinya kabinet sering menimbulkan ketidakstabilan dalam bidang politik, ekonomi, sosial, dan keamanan. Ciri-ciri demokrasi liberal adalah sebagai berikut: Presiden dan Wakil Presiden tidak dapat diganggu gugat, Menteri bertanggung jawab atas kebijakan pemerintah, Presiden bisa dan berhak berhak membubarkan DPR, dan Perdana Menteri diangkat oleh Presiden.

Praktik demokrasi pada masa ini dinilai gagal disebabkan oleh: Dominannya partai politik, landasan sosial ekonomi yang masih lemah, tidak mampunya konstituante bersidang untuk mengganti UUDS 1950. Atas dasar kegagalan itu maka Presiden mengeluarkan Dekrit Presiden 5 Juli 1959: 1. Bubarkan konstituante, 2. Kembali ke UUD 1945 tidak berlaku UUD S 1950, 3. Pembentukan MPRS dan DPAS 
2. Masa Demokrasi Terpimpin (1959-1965)

Demokrasi terpimpin adalah sebuah sistem demokrasi dimana seluruh keputusan serta pemikiran berpusat pada pemimpin negara. Konsep sistem Demokrasi Terpimpin pertama kali diumumkan oleh Presiden Soekarno dalam pembukaan sidang konstituante pada tanggal 10 November 1956. Masa demokrasi terpimpin (1957-1965) dimulai dengan tumbangnya demokrasi parlementer atau demokrasi liberal yang ditandai pengunduran Ali Sastroamidjojo sebagai perdana menteri. Namun begitu, penegasan pemberlakuan demokrasi terpimpin dimulai setelah dibubarkannya badan konstituante dan dikeluarkannya dekrit presiden 5 Juli 1959. ${ }^{3}$

Pengertian demokrasi terpimpin menurut Tap MPRS No. VII/MPRS/1965 adalah kerakyatan yang dipimpin oleh hikmat kebijaksanaan dalam permusyawaratan perwakilan yang berintikan musyawarah untuk mufakat secara gotong royong diantara semua kekuatan nasional yang progresif revolusioner dengan berporoskan nasakom dengan ciri: dominasi Presiden, terbatasnya peran partai politik, dan berkembangnya pengaruh PKI.

Ketegangan-ketegangan politik yang terjadi pasca Pemilihan Umum 1955 membuat situasi politik tidak menentu. Kekacauan politik ini membuat keadaan negara menjadi dalam keadaan darurat. Hal ini diperparah dengan Dewan Konstituante yang mengalami kebuntuan dalam menyusun konstitusi baru, sehingga negara Indonesia tidak mempunyai pijakan hukum yang mantap. Berikut latar belakang munculnya penerapan demokrasi terpimpin oleh Presiden Soekarno.

Penyimpangan masa demokrasi terpimpin antara lain: Mengaburnya sistem kepartaian, pemimpin partai banyak yang dipenjarakan, peranan parlemen lemah bahkan akhirnya

http://tifiacerdikia.wordpress.com/lecture/lecture-I/ilmu kewarganegaraan/perkembangandemokrasi-di-indonesia, diakses 6 Maret 20I4. 
dibubarkan oleh presiden dan presiden membentuk DPRGR, jaminan HAM lemah, terjadi sentralisasi kekuasaan, terbatasnya peranan pers, kebijakan politik luar negeri sudah memihak ke RRC (Blok Timur). Akhirnya terjadi peristiwa pemberontakan G 30 September 1965 oleh PKI yang menjadi tanda akhir dari pemerintahan Orde Lama.

3. Pelaksanaan Demokrasi Masa Orde Baru (1966-1998)

Dinamakan juga demokrasi pancasila. Pelaksanaan demokrasi orde baru ditandai dengan keluarnya Surat Perintah 11 Maret 1966, Orde Baru bertekad akan melaksanakan Pancasila dan UUD 1945 secara murni dan konsekwen. Awal Orde baru memberi harapan baru pada rakyat pembangunan disegala bidang melalui Pelita I, II, III, IV, V dan pada masa orde baru berhasil menyelenggarakan Pemilihan Umum tahun 1971, 1977, 1982, 1987, 1992, dan 1997.

Demokrasi yang secara resmi mengkristal di dalam UUD 1945 dan saat ini berlaku di Indonesia biasa disebut "demokrasi pancasila". Meskipun sebenarnya dasar-dasar konstitusional bagi demokrasi di Indonesia sebagaimana yang berlaku sekarang ini sudah ada dan berlaku jauh sebelum tahun 1965, tetapi istilah "demokrasi pancasila" itu baru dipopulerkan sesudah lahir orde baru 1966.

Istilah ini lahir sebagai lawan (dilawankan) terhadap istilah "Demokrasi Terpimpin" di bawah pemerintahan Soekarno. Sebagaimana akan diuraikan dalam bab berikutnya sejak tahun 1957/1958 Soekarno mencetuskan ide "Demokrasi Terpimpin" sebagai usaha pemusatan kekuasaan berada di tangannya. Gagasan ini kemudian berhasil dibakukan secara yuridis dalam bentuk ketetapan MPRS No. VIII/MPRS/1965 tentang "Prinsip-prinsip Musyawarah untuk Mufakat dalam Demokrasi Terpimpin sebagai Pedoman bagi Lembagalembaga Permusyawaratan/Perwakilan". Ketika orde baru lahir gagasan Demokrasi Terpimpin ditolak secara terang- 
terangan sehingga pada tahun 1968 kembali MPRS mengeluarkan Ketetapan no. XXXVII/MPRS/1968 tentang Pencabutan Ketetapan MPRS No. VIII/MPRS/1965 dan tentang Pedoman Pelaksanaan Kerakyatan yang Dipimpin oleh Hikmah Kebijaksanaan dalam Permusyawaratan/Perwakilan atau sesuai dengan diktum Tap tersebut tentang Demokrasi Pancasila. Dengan demikian perwujudannya sebagai aturan hukum baik Demokrasi Terpimpin maupun Demokrasi Pancasila itu adalah berisi teknis pelaksanaan pengambilan keputusan dalam permusyawaratan. Menurut Demokrasi Terpimpin inti dari Permusyawaratan adalah "musyawarah untuk mufakat" yang bilamana hal itu tidak dapat dicapai maka musyawarah harus menempuh salah satu jalan berikut:

a. Persoalannya diserahkan kepada pemimpin untuk mengambil kebijaksanaan dengan memperhatikan pendapat-pendapat yang bertentangan.

b. Persoalannya ditangguhkan.

c. Persoalannya ditiadakan sama sekali.

Sedangkan konsep Demokrasi pancasila juga mengutamakan nusyawarah untuk mufakat, tetapi pemimpin tidak diberi hak untuk mengambil keputusan sendiri dalam hal "mufakat bulat" tidak tercapai. Bagi Demokrasi Pancasila sesuai Tap MPRS No. XXXVII/MPRS/1968 untuk mengatasi kemacetan karena tidak dapat dicapainya "mufakat bulat" maka jalan voting (pemungutan suara) bisa ditempuh sesuai dengan prosedur yang dikehendaki pasal 2 Ayat (3) dan pasal 6 Ayat (2) UUD 1945. Perumusan Demokrasi Pancasila sebagaimana diatur Tap No. XXXVII/MPRS/1968 yang sekedar mengatur teknis musyawarah ini pada tahun 1973 kembali dicabut dengan Tap No. V/MPR/1973 bersama dengan pencabutan terhadap beberapa produk MPR lainnya 
yang dianggap tidak dapat dipakai lagi sebagai peraturan perundang-undangan. ${ }^{4}$

Tetapi lebih dari sekedar soal teknis prosedural upaya memberikan pengertian bagi "Demokrasi Pancasila" sudah banyak dikemukakan. Pejabat presiden Soeharto pada pidato kenegaraan tanggal 16 Agustus 1967, antara lain menyatakan bahwa Demokrasi Pancasila berarti demokrasi, kedaulatan rakyat yang dijiwai dan diintegrasikan dengan sila-sila lainnya. Hal ini berati bahwa dalam menggunakan hak-hak demokrasi haruslah selalu disertai dengan rasa tanggung jawab kepada Tuhan Yang Maha Esa menurut keyakinan agama masing-masing, haruslah menjunjung tinggi nilai-nilai kemanusiaan sesuai dengan harkat dan martabat manusia, haruslah menjamin dan mempersatukan bangsa, dan harus dimanfaatkan untuk mewujudkan keadilan sosial. Pancasila berpangkal tolak dari paham kekeluargaan dan gotongroyong. Sebelum itu seminar II Angkatan Darat yang berlangsung pada bulan Agustus 1966 mengeluarkan "GarisGaris Besar Kebijaksanaan dan Rencana Pelaksanaan Stabilisasi Politik" yang dalam bidang Politik dan Konstitusional dirumuskan dengan:

"Demokrasi Pancasila seperti yang dimaksud dalam UndangUndang Dasar 1945, yang berarti menegakkan kembali asasasas negara hukum di mana kepastian hukum dirasakan oleh segenap warga negara, di mana hak-hak asasi manusia baik dalam aspek kolektif, maupun dalan aspek perorangan dijamin, dan di mana penyalahgunaan kekuasaan dapat dihindarkan secara inkonstitusional. Dalam rangka ini perlu diusahakan supaya lembaga-lembaga dan tata kerja Orde Baru dilepaskan dari ikatan-ikatan pribadi dan lebih diperlembagakan (deperzonalization, institusinalization)".

${ }^{4}$ Moh. Mahfud MD, Demokrasi dan Konstitusi di Indonesia: Studi Tentang Interaksi Politik dan Kehidupan Ketatanegaran, (Jakarta: PT Rineka Cipta, 2003), 42. 
Dari sudut hubungan antar lembaga-lembaga negara atau antar aparatur demokrasi terlihat bahwa Demokrasi Pancasila sebagaimana diatur dalam UUD 1945 memberikan kekuasaan yang besar kepada presiden. Presiden dipilih dan diangkat oleh MPR yang separo anggotanya adalah anggotaanggota DPR. Kekuasaan presiden ini besar karena ia tidak bisa dijatuhkan oleh DPR. Memang DPR bisa mengusulkan sidang istimewa MPR untuk meminta pertanggungjawaban Presiden sebagai mandataris MPR jika Presiden dianggap sungguh-sungguh melanggar haluan negara, tetapi prosedur atau persyaratan untuk ini tidaklah mudah karena harus melalui tahap-tahap memorandum tertentu. Oleh karena itu jika seorang Presiden sudah dipilih dan diangkat oleh MPR maka ia mamegang kekuasaan yang besar untuk terus memerintah sampai habis masa jabatannya. Pada pihak lain, DPR sebenarnya mempunyai pengaruh dalam sistem politik karena (seharusnya) dewan ini menyalurkan aspirasi dan tuntutan-tuntutan rakyat. Presiden tidak dapat membubarkan DPR, sebagaimana DPR tidak dapat menjatuhkan Presiden; dan untuk itu Presiden perlu memperhatikan suara-suara anggota DPR. Secara tidak langsung Demokrasi Pancasila menghendaki terjadinya hubungan yang harmonis antar eksekutif dan legislatif melalui proses konsensus sehingga keseimbangan yang wajar antara konsensus dan konflik akan tercipta.

Wilopo mengemukakan bahwa di dalam sistem UUD 1945 jelas ada keseimbangan atau checks and balances yang khas antara Pemerintah dan DPR; DPR kuat karena tidak dapat dibubarkan oleh Pemerintah dan begitu pula pemerintah kuat karena tidak dapat dijatuhkan oleh DPR.

Namun demikian perjalanan demokrasi pada masa orde baru ini dianggap gagal disebabkan beberapa hal: rotasi kekuasaan eksekutif hampir dikatakan tidak ada, rekrutmen politik yang tertutup, Pemilu yang jauh dari semangat 
demokratis, pengakuan HAM yang terbatas, dan tumbuhnya KKN yang merajalela.

Demokrasi pancasila berakhir dengan jatuhnya Orde Baru yang disebabkan hancurnya ekonomi nasional (krisis ekonomi), terjadinya krisis politik, TNI juga tidak bersedia menjadi alat kekuasaan orba, dan gelombang demonstrasi yang menghebat menuntut Presiden Soeharto untuk turun jadi Presiden. Berakhirnya masa orde baru ditandai dengan penyerahan kekuasaan dari Presiden Soeharto ke Wakil Presiden BJ Habibie pada tanggal 21 Mei 1998.

4. Pelaksanaan Demokrasi Masa Transisi (1998-1999)

Masa transisi berlangsung tahun 1998-1999. Pada masa ini terjadi penyerahan kekuasaan dari Presiden Soeharto yang mengundurkan diri kepada Wakil Presiden B. J. Habibie pada tanggal 21 Mei 1998, jadi Presiden RI pada waktu itu digantikan oleh B. J. Ha Habibie. Hal ini disebut masa transisi, yaitu perpindahan pemerintahan.

Presiden BJ.Habibie, sebagai bagian dari rezim masa lalu, memahami benar kondisi obyektif rezim orde baru dalam hal pelanggaran HAM sehingga langkah-langkah politik yang ia lakukan di awal-awal kekuasaannya menunjukkan kesungguhan untuk membangun negara hukum dan demokrasi. Ia melepaskan sejumlah tahanan politik, membuka kebebasan pers dan berpendapat, mencabut UU subversif dan kebijakan-kebijakan yang berkaitan dengan penghormatan, perlindungan dan penegakkan HAM.

Hal yang dilakukan BJ. Habibie di awal pemerintahannya itu suatu permulaan penting dalam transisi demokrasi yang memang harus dilakukannya. Secara empiris rangkaian panjang pelanggaran HAM selama orde baru bukan saja telah membuat citra kekuasaan kurang positif di mata rakyat, tetapi juga menjadi sebab kegagalan orde baru mempertahankan kekuasaannya setelah puluhan tahun menyangga kekuasaan otoritarian. 
Pemerintahan baru pascaorde baru menyusun desain transisi dan konsolidasi demokrasi dengan memulai suatu politik hukum pemulihan hak-hak politik warga negara, serta menjamin kelangsungannya melalui pelbagai regulasi dan deregulasi sebagaimana telah disinggung secara singkat di muka. Politik hukum transisional masa kekuasaan BJ. Habibie jauh berbeda dengan era kekuasaan Soeharto. Masa Soeharto, merupakan masa yang digunakan untuk menemukan format politik yang sesuai dengan kehendak Soeharto, yaitu stabilitas politik sebagai basis bagi pembangunan ekonomi nasional. Dalam masa tersebut, menurut Affan, Soeharto berhasil mengembangkan kekuasaannya dengan mengombinasikan mekanisme "carrots and sticks". Untuk mereka yang mendukungnya, Soeharto dengan mudah memberikan reward berupa kedudukan dan jabatan, sementara yang menentangnya akan disingkirkan dari panggung politik nasional dengan seperangkat alat yang bersifat represif.

Agenda utama yang harus dilakukan B.J. Habibie dalam melaksanakan transisi politik, mempercepat pemilihan umum (pemilu), serta menegakkan supremasi hukum dan kebijakan penghormatan dan penegakan HAM, khususnya dalam penyelesaian pelanggaran HAM masa lalu. Agenda pemilu didesakkan oleh kekuatan pro demokrasi dalam negeri untuk dilakukan secepat mungkin sebagai proses formal demokratik mengakhiri jejak rezim orde batu atau dalam pandangan Huntington sebagai "tanda" berakhirnya rezin nondemokratik (the inaguration on non-democratic rezim), sekaligus sebagai "pelembagaan demokrasi" dan pembangunan kembali kohesi sosial yang telah retak akibat tarik-menarik dukungan dan penolakan antara perbagai kelompok sosial dalam masyarakat. Pemilu juga bermakna sebagai pelantikan pemerintahan baru atau rezim demokratik (the inaguration of the democratic rezim) yang menggantikan pemerintahan otoriter yang telah tumbang. Pemilu juga 
dimaknai sebagai perwujudan konsolidasi sistem demokrasi (the inaguration of the democratic system), yaitu suatu usaha untuk menjaga secara ketat kembalinya rezim status quo untuk menduduki kursi kekuasaan.

5. Demokrasi Masa Reformasi (1999-Sekarang)

Demokrasi yang dikembangkan pada masa reformasi pada dasarnya adalah demokrasi dengan mendasarkan pada Pancasila dan UUD 1945, dengan penyempurnaan pelaksanaannya dan perbaikan peraturan-peraturan yang tidak demokratis, dengan meningkatkan peran lembagalembaga tinggi dan tertinggi negara dengan menegaskan fungsi, wewenang dan tanggung jawab yang mengacu pada prinsip pemisahan kekuasaan dan tata hubungan yang jelas antara lembaga-lembaga eksekutif, legislatif dan yudikatif. Demokrasi Indonesia saat ini telah dimulai dengan terbentuknya DPR - MPR hasil Pemilu 1999 yang telah memilih presiden dan wakil presiden serta terbentuknya lembaga-lembaga tinggi yang lain. Masa reformasi berusaha membangun kembali kehidupan yang demokratis antara lain:

a. Keluarnya Ketetapan MPR RI No. X/MPR/1998 tentang pokok-pokok reformasi

b. Ketetapan No. VII/MPR/1998 tentang pencabutan tap MPR tentang Referandum

c. Tap MPR RI No. XI/MPR/1998 tentang penyelenggaraan Negara yang bebas dari KKN

d. Tap MPR RI No. XIII/MPR/1998 tentang pembatasan Masa Jabatan Presiden dan Wakil Presiden RI

e. Amandemen UUD 1945 sudah sampai amandemen I, II, III, IV

Prinsip demokrasi atau kedaulatan rakyat dapat menjamin peran serta masyarakat dalam proses pengambilan keputusan, sehingga setiap peraturan perundang-undangan yang diterapkan dan ditegakkan benar-benar mencerminkan perasaan keadilan masyarakat. Hukum dan peraturan 
perundang-undangan yang berlaku tidak boleh ditetapkan dan diterapkan secara sepihak oleh dan atau hanya untuk kepentingan penguasa. Hal ini bertentangan dengan prinsip demokrasi. Hukum tidak dimaksudkan untuk hanya menjamin kepentingan beberapa orang yang berkuasa, melainkan menjamin kepentingan keadilan bagi semua orang. ${ }^{5}$

Perubahan UUD 1945, selain mengubah norma-norma yang memungkinkan prinsip-prinsip negara hukum dapat diwujudkan, juga mengubah norma-norma demokrasi agar demokrasi prosedural dan demokrasi substantif juga dapat diwujudkan. Kalau diperhatikan secara menyeluruh, materi perubahan pertama, kedua, ketiga dan keempat UUD 1945 meliputi:

a. Mempertegas pembatasan kekuasaan presiden dimana jika sebelum perubahan, UUD 1945 memberikan kekuasaan kepada lembaga kepresidenan begitu besar (executive heavy), yang meliputi kekuasaan eksekutif, legislatif dan yudikatif sekaligus, kini kekuasaan presiden terbatas pada kekuasaan eksekutif saja;

b. Mempertegas ide pembatasan kekuasaan lembaga negara, yang terlihat dalam pengaturan tentang kewenangan lembaga negara yang lebih terinci;

c. Menghapus keberadaan lembaga negara tertentu (DPA) dan membentuk lembaga-lembaga negara yang baru seperti Mahkamah Konstitusi (MK), Komisi Yudisial (KY), Dewan Perwakilan Daerah (DPD), Komisi Pemilihan Umum (KPU) dan Bank Sentral;

d. Mempertegas dan memperinci jaminan terhadap perlindungan HAM warga negara;

e. Mempertegas dianutnya teori kedaulatan rakyat, yang selama ini lebih terkesan menganut teori kedaulatan 
negara. Hal ini terlihat dari dihapusnya klaim politik bahwa MPR adalah "pemegang kedaulatan rakyat sepenuhnya", dimaksudkannya konsep pemilihan umum dalam mengisi jabatan anggota DPR, DPD dan DPRD serta digunakannya sistem pemilihan langsung oleh rakyat untuk mengisi jabatan presiden dan wakil presiden, serta pemilihan kepala daerah dan wakil kepala daerah.

Secara spesifik, amandemen konstitusi Indonesia menghasilkan sejumlah desain baru format kenegaraan sebagai berikut:

a. Presiden dan wakil presiden dipilih melalui pemilu langsung oleh rakyat, sedangkan kewenangan MPR hanya sebatas melantik presiden dan wakil presiden terpilih saja. Oleh karena itu. Masing-masing lembaga negara sama-sama memiliki legitimasi politik yang kuat dan bertanggung jawab langsung kepada pemegang kedaulatan asli yaitu rakyat.

b. Kedaulatan rakyat dilaksanakan oleh berbagai lembaga negara sesuai dengan bidang tugasnya masing-masing menurut konstitusi UUD 1945. Hal ini terlihat dari adanya pembagian tugas masing-masing lembaga negara yang makin jelas dan terperinci sehingga menghindari terjadinya tumpang tindih dan intervensi kewenangan antarlembaga negara. Presiden memegang kekuasaan menjalankan pemerintahan. DPR dan DPD dapat mengawasi jalannya pemerintahan yang dilaksanakan oleh presiden dan kabinetnya dan lembaga peradilan dalam hal ini MA dan MK memiliki wewenang melakukan kontrol yuridis lewat judicial review baik terhadap kebijakan yang diambil oleh presiden sebagai pemegang kekuasaan eksekutif maupun terhadap kebijakan yang dibuat oleh DPR berupa produk undangundang, yaitu eksekutif, legislatif dan yudisial. 
c. Adanya jaminan terciptanya stabilitas jalannya pemerintahan karena jabatan presiden dibatasi dalam masa jabatan lima tahun dan hanya dapat diberhentikan oleh MPR dalam kondisi tertentu saja berdasarkan UUD, serta melalui mekanisme hukum, yaitu pembuktian hukum oleh MK. Dengan demikian, presiden tidak dapat diusulkan oleh DPR untuk diberhentikan semata-mata karena alasan konflik politik. Demikian pula presiden dilarang untuk membekukan dan/atau membubarkan DPR.

Perubahan terhadap UUD 1945 sebanyak empat kali, sebagaimana telah disebutkan dimuka mempertegas dua hal kerangka hukum dasar demokrasi sekaligus, yaitu demokrasi prosedural berupa ditetapkannya prosedur dan mekanisme penentuan puncak jabatan politik eksekutif baik nasional maupun daerah melalui pemilu langsung oleh rakyat. Perubahan ini menempatkan warga negara sebagai subyek hukum yang memiliki makna dan nilai politik serta hukum sekaligus dalam penentuan jabatan-jabatan politik.

Perubahan UUD 1945 juga menegaskan prinsip perimbangan kekuasaan eksekutif, legislatif dan yudikatif sebagai salah satu esensi demokrasi. Dengan UUD 1945 hasil perubahan tersebut, kekuasaan presiden menjadi terbatas dalam masa jabatan dan penggunaan kekuasaan presiden, sekaligus juga terkontrol oleh kekuasaan legislatif dan yudikatif. Ketentuan Pasal 7C UUD 1945 tentang larangan bagi presiden membekukan atau membubarkan DPR menunjukkan eksistensi kelembagaan DPR yang kuat dalam mengawasi presiden tanpa dihantui ketakutan dibubarkan oleh presiden, termasuk kewenangan DPR mengusulkan pemberhentian presiden jika kinerja tidak baik atau melanggar UUD 1945.

Elemen demokrasi lainnya yang berubah hampir seratus persen dalam perubahan ketiga UUD 1945 adalah kekuasaan 
kehakiman yang termuat dalam Pasal 24, 24A, 24B, 24C dan Pasal 25. Substansi perubahan tersebut adalah kemerdekaan kekuasaan kehakiman sebagai jawaban terhadap kelemahan UUD 1945 sebelum perubahan yang menempatkan kekuasaan kehakiman di bawah kekuasaan eksekutif. Kemerdekaan kekuasaan kehakiman yang diatur dalam perubahan ketiga meliputi kemerdekaan atau independensi struktural, fungsional dan personal.

Independensi struktural kekuasaan kehakiman menempatkan institusi negara ini pada struktur tersendiri yang tidak berada di bawah atau di samping kekuasaan eksekutif dan atau legislatif. Pasal 24 ayat (1), (2) dan (3), Pasal 24A ayat (5), Pasal 24B ayat (1) dan ayat (4) adalah pasal-pasal yang menegaskan independensi struktural kekuasaan kehakiman. Hal yang ditegaskan dalam pasalpasal tersebut merupakan legalisasi atau keinginan pembinaan kekuasaan kehakiman dalam satu atap.

Sementara itu Pasal 24A ayat (1), 24B ayat (1), 24C ayat (1) dan Pasal 24C ayat (2) adalah pasal-pasal yang menjamin kemerdekaan atau independensi fungsional, sedangkan independensi personal diatur dalam Pasal 24A ayat (2) dan ayat (4), Pasal 24B ayat (2), Pasal 24C dan ayat (5). Syaratsyarat dan mekanisme penentuan hakim MA, hakim MK, dan anggota KY menunjukkan jaminan kemerdekaan personal, meskipun keterlibatan DPR dalam mekanisme penentuan ketiga lembaga yudisial itu menjadi faktor yang mereduksi independensi personal ketiga anggota lembaga. Kedepan keterlibatan DPR seharusnya dihilangkan karena dari sudut substansi, kewenangan dan eksistensi DPR sebagai representasi partai politik, keterlibatan DPR itu justru mereduksi substansi dan kredibilitas semangat UUD 1945 Perubahan yang mengedepankan kemandirian kekuasaan kehakiman sebagai salah satu perubahan mendasar dalam negara hukum dan demokrasi yang sedang dibangun. 
Kemerdekaan atau independensi kekuasaan kehakiman yang semakin kuat dibanding sebelumnya sesungguhnya memberikan harapan bagi tegaknya hukum, keadilan dan perlindungan HAM karena dalam sistem negara modern, cabang kekuasaan kehakiman memang harus diorganisasikan tersendiri karena prinsip pemisahan kekuasaan menempatkan kekuasaan kehakiman pada dimensi sangat penting. Di samping itu, kemerdekaan kekuasaan kehakiman itu adalah garansi konstitusional terhadap tegaknya hukum dan keadilan, garansi bagi proteksi HAM dari kesewenangwenangan kekuasaan, serta garansi adanya mekanisme memperjuangkan pemenuhan HAM yang diabaikan oleh undang-undang sebagaimana tugas dan kewenangan MK.

\section{Civil Society dan Demorasi Indonesia}

Ketika reformasi mulai digulirkan pada tahun 1998, semua perhatian tertumpah pada kelompok mahasiswa, organisasi nonpemerintah (ORNOP), dan figur politik yang secara mendadak dibuat menjadi "pahlawan reformasi". Pada saat yang sama terlupakan bahwa di dalam "revolusi Mei 1998" yang diwarnai oleh kerusuhan anti-China- pengrusakan, penjarahan, penyiksaan, pemerkosaan, dan bahkan pembunuhan sehingga merupakan salah satu yang terburuk dalam sejarah Indonesia modern - yang melibatkan preman, milisi, berbagai kelompok anti-China, dan kelompok-kelompok keagamaan ekstrim lainnya. Suka atau tidak, momen yang dapat disebut sebagai "kemenangan civil society" yang mewarnai kejatuhan rezim Soeharto ternyata terkontaminasi oleh kekerasan. Noda ynag mencoreng wajah reformasi cepat terlupakan ketika transisi menuju demokrasi ternyata tidak berjalan mulus. Berbagai kekuatan anti-reformasi dan kaum reformis setengah hati yang berlomba-lomba untuk menghapus dosa atau memenangkan dukungan dari kaum ekstrim dan garis keras melakukan berbagai upaya sehingga mereka yang paling bertanggungjawab terhadap kerusuhan tersebut tidak pernah 
diadili. Hingga saat ini, mereka yang diadili dan dihukum hanya terbatas pada "pelaku-pelaku lapangan"yang tertangkap basah ketika melakukan pengrusakan maupun penjarahan. Tidak satu pun upaya dilakukan untuk memproses secara hukum mereka yang membuat dan menyebarkan "teori konspirasi" sehingga menyulut kerusuhan dan memobilisasi massa untuk melakukan pengrusakan, penganiayaan, pemerkosaan dan sebagainya. ${ }^{6}$

Peristiwa Mei 1998 menunjukkan bahwa gerakan yang pada akhirnya menjatuhkan rezim otoriter dan membuka jalan menuju demokrasi ternyata melibatkan civil society dengan dua wajahnya sekaligus, baik dan buruk. Dalam wajahnya ynag baik, civil society yang diwakili oleh kelompok mahasiswa, ORNOP, dan intelektual kampus bersama-sama ikut dalam gerakan menentang orde baru yang sekaligus membuka jalan bagi demokrasi. Dalam wajahnya yang buruk, civil society (yang diwakili oleh kaum preman, para militer, dan kaum ekstrimis) telah menciptakan ketidakstabilan sosial, teror, dan bahkan kemudian konflik horizontal di tengahtengah masyarakat. Hal tersebut menunjukkan bahwa reformasi juga melibatkan apa yang disebut sebagai "uncivil" atau "bad" civil society yang mengambil keuntungan dari situasi kacau untuk kepentingan mereka sendiri, yakni melampiaskan hawa nafsu chauvinis dan kehausan mereka akan kekuasaan.

Pada masa kejatuhan rezim otoriter, salah satu tahap demokrasi yang paling krusial adalah "konsolidasi". Larry Diamond mendefinisikan konsolidasi sebagai tahap di mana para aktor politik (di kalangan elit maupun massa) dalam jumlah yang signifikan meyakini bahwa demokrasi merupakan satu-satunya norma dan instrumen politik yang secara realistis dapat diberlakukan. Sementara itu, Juan Linz dan Alfred Stepan menyatakan bahwa suatu masyarakat dapat dikatakan mencapai tahap konsolidasi jika pihak-pihak yang terlibat dalam kompetisi politik (untuk memperebutkan kekuasaan di pemerintahan

\footnotetext{
${ }^{6}$ Bob Sugeng Hadiwinata, Demokrasi di Indonesia, (Yogyakarta: Graha Ilmu, 20 I 0), 230.
}

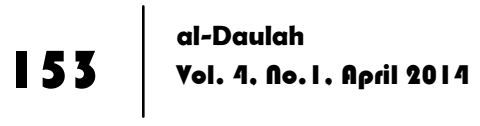


maupun legislatif) meyakini bahwa demokrasi (termasuk sistem hukum, lembaga, dan prosedur ynag menyertainya) merupakan satu-satunya aturan main yang berlaku (the only game in town), yakni satu-satunya kerangka yang mengatur pencapaian kepentingan.

Bagi para teoritisi transisi menuju demokrasi tersebut, segala bentuk penolakan terhadap demokrasi apa yang oleh Juan Linz disebut "manifestation of disloyalty" cenderung menciptakan kerentanan, instabilitas politik, dan bahkan kemunduran proses demokrasi. Dengan kata lain, demokrasi dapat terancam jika terdapat elemen di dalam masyarakat yang mempergunakan caracara paksaan dan kekerasan untuk memaksakan kehendak mereka tanpa memberikan toleransi terhadap pihak lain yang juga merupakan bagian dari komunitas tertentu. Sebagaimana dinyatakan oleh Larry Diamond: "jika demokrasi ingin mencapai tahap konsolidasi, maka eksistensi berbagai kekuatan yang mengandalkan para ekstrimisme, pemaksaan dan kekerasan harus dibatasi seminimal mungkin. Jika tidak, maka demokrasi akan menjurus pada kekacauan yang berkepanjangan dan bahkan kebangkrutan."

\section{Uncivil Society dan Ancaman Terhadap Demokrasi}

Bagaimana cara civil society mengancam demokrasi? Indonesia merupakan contoh yang menarik dibicarakan. Di Indonesia, apa yang oleh Juan Linz disebut dengan manifestion of disloyalty datang dari kelompok-kelompok ekstrim etniskeagamaan. Kelompok keagamaan memiliki porsi lebih besar seiring dengan meningkatnya ketegangan antar kelompok agama. Sekalipun banyak kelompok ekstrim Islam dibentuk pada masa pasca Soeharto, keberadaan ekstrim Islam sebenarnya dapat ditelusuri sejak awal dekade 1990-an. Terdapat sekurangkurangnya tiga faktor yang mendorong kebangkitan ekstrimisme Islam di Indonesia pada waktu itu. pertama, konflik etno religius di Balkan dimana kaum muslim Bosnia menjadi korban kekejaman 
tentara Serbia. Solidaritas terhadap kaum minoritas Bosnia sekejab berubah menjadi semangat anti-Kristen yang ditandai dengan kemunculan berbagai kelompok ekstrim yang mencari-cari kesempatan untuk mencederai kaum minoritas Kristen. Peristiwa di Situbondo dan Tasikmalaya pada tahun 1996 merupakan contoh yang paling konkrit, dimana kaum ekstrim melakukan "pembalasan" dengan membakar puluhan gereja dan sekolah. Kedua, kebangkitan semangat "mayoritarianisme" di kalangna kaum muslim konservatif. Bagi mereka, sebagai warga mayoritas, kaum muslim berhak menuntut kontrol lebih besar terhadap berbagai aspek kehidupan: politik, sosial, ekonomi. Melalui tulisan di berbagai media dan ceramah di seminar-seminar, beberapa cendikiawan muslim menyuarakan ketidakadilan yang dihadapi mayoritas muslim. Sejak saat itu, hubungan antar agama menjadi semakin tegang sehingga memunculkan berbagai organisasi bernuansa keagamaan seperti ICMI, PIKI, PHI, ISKA, dan sebagainya. Ketiga, upaya Soeharto untuk memenangkan hati kaum Muslim dengan meninggalkan pendekatan represif yang selama ini diterapkan terhadap kelompok-kelompok garis keras. Pengenduran kontrol ini dimanfaatkan oleh kaum ultrakonservatif untuk membentuk organisasi-organisasi baru atau mengaktifkan kembali organisasi-organisasi yang selama ini bergerak di "bawah tanah" akibat represi pemerintahan orde baru.

Etnisitas juga merupakan aspek di mana civil society berpotensi untuk menghancurkan demokrasi. Situasi hubungan antar etnis di Indonesia pasca Orde Baru seolah-olah membenarkan pendapat Jack Snyder bahwa demokratisasi yang dilakukan secara tiba-tiba di dalam masyarakat yang pluralistik berpotensi untuk menyulut konflik dan kekerasa internal sehingga menciptakan instabilitas politik. Beberapa saat setelah reformasi digulirkan, konflik etnis segera merebak. Di Kalimantan Tengah, sentimen anti-Madura di kalangan penduduk asli Dayak makin berkembang seiring dengan meningkatnya marjinalisasi di kalangan masyarakat Dayak. Sekalipun kaum imigran Madura 
hanya 7 persen dari total penduduk di Kalimantan Tengah, mereka memiliki andil yang besar di berbagai sektor ekonomi seperti transportasi (darat dan sungai), pertambangan, perkayuan (logging), dan perdagangan (formal maupun informal). Generasi pertama kaum pendatang Madura datang ke wilayah tersebut pada dekade 1960-an sebagai transmigran, yang disusul dengan gelombang pendatang yang lebih besar pada dekade 1970-an dan 1980-an. Tidak sedikit dari mereka yang sukses dalam usaha perhotelan, restoran, pompa bensin, angkutan umum, perdagangan sembako, dan lain-lain. Selama beberapa dekade, peningkatan kesejahteraan kaum pendatang Madura ini ternyata berjalan seiring dengan marjinalisasi penduduk asli Dayak. Akibatnya, kebencian etnis di kalangan Dayak semakin memuncak.

Insiden kecil yang melibatkan kedua suku sudah cukup untuk menyulut kerusuhan yang lebih besar. Pada tanggal 15 Desember 2000, sebuah perkelahian antara kelompok pemuda Madura dan Dayak di sebuah bar karaoke di Kereng Pangi telah menyulut kerusuhan etnis yang mengerikan. Isu bahwa seorang Dayak terbunuh dalam perkelahian tersebut telah memobilisasi para pemuda Dayak untuk menyerang pemukiman, toko dan kantor milik orang Madura di kota sampit, sehingga memaksa sekitar 1000 orang untuk lari ke hutan-hutan di sekitarnya. Pembalasan yang dilakukan kaum Madura beberapa hari kemudian ternyata memicu kerusuhan yang lebih besar dan berdarah. Selama Februari hingga Maret 2001, pembunuhan terhadap etnis Madura terus berlangsung dan melebar ke kotakota lain seperti Palangkaraya, Panglakan Bun, dan Kuala Kapuas. Diperkirakan 400 orang Madura tewas terbunuh dan 108.000 lainnya mengungsi ke berbagai tempat di Jawa Timur. ${ }^{7}$

Baik fenomena konflik agama maupun etnis sebagaimana digambarkan di atas menunjukkan bahwa civil society tidak kebal

${ }^{7}$ Ibid., 234.

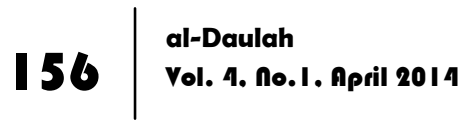


terhadap kemungkinan untuk dijadikan alat oleh kalangan masyarakat tertentu (biasanya yang memiliki ambisi politik berlebihan tetapi tidak memiliki cukup modal sosial-ekonomis untuk mencapainya) untuk menjalankan hal-hal yang membuat mereka menjadi "uncivil society" atau "bad civil society". Jika situasinya demikian, maka demokrasi tidak lagi dapat mengandalkan pada civil society dalam rangka untuk mencapai tahap konsolidasi.

\section{Penutup}

Tidaklah mungkin membangun hukum yang responsif tanpa terlebih dahulu membangun sistem politik yang demokratis, sebab hukum responsif tidak mungkin lahir di dalam sistem politik yang otoriter. Melalui amandemen konstitusi (1999-2002) Indonesia telah membuat struktur dan pola hubungan kekuasaan negara yang dari sudut ketatanegaraan lebih menjamin tampilnya sistem politik yang demokratis. Meskipun begitu ada dua hal yang harus diperhatikan untuk selalu mengaktualisasikan sistem yang demokratis itus:

Pertama, sistem demokrasi yang telah dikukuhkan melalui amandemen konstitusi haruslah diikuti dengan moralitas atau semangat untuk mewujudkannya oleh penyelenggara negara, sebab sistem dan semangat penyelenggara negara itu sama pentingnya.

Kedua, sebagai produk kesepakatan (resultante) yang lahir dari keadaan dan waktu tertentu UUD itu tidak boleh ditutup dari kemungkinan untuk diubah dengan resultante baru. UUD yang merupakan hasil amandemen pun harus membuka kemungkinan untuk diamandemen lagi dengan resultante baru jika keadaan dan waktu menuntut dilakukannya hal itu. Meskipun begitu bukan berarti Undang-Undang dasar itu dapat dengan mudah diubah dengan resultante baru tanpa alasan yang ketat. Perubahan hanya

\footnotetext{
${ }^{8}$ Moh.Mahfud MD, Politik Hukum di Indonesia, (Jakarta: PT Raja Grafindo Persada, 20 I2), 380.
}

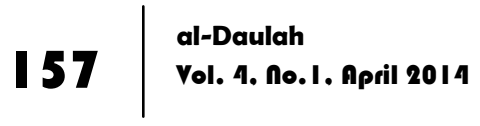


dapat dilakukan dengan alasan-alasan yang sangat penting dan dengan prosedur yang tidak mudah. Para ahli konstitusi menyebutkan dua hal penting yang harus diperhatikan dalam pembuatan dan muatan konstitusi: Pertama, muatan konstitusi harus bersifat mendasar dan abstrak-umum; tidak membuat halhal konkrit, teknis, dan kuantitatif agar tidak terlalu sering menghadapi tuntutan perubahan. Kedua, konstitusi harus memuat prosedur perubahan yang tidak mudah dilakukan kecuali dengan alasan-alasan yang sangat penting; misalnya harus ada ketentuan tentang jumlah minimal pengusul perubahan isi konstitusi dan kuorum minimal dalam pengambilan keputusan untuk mengubah isi konstitusi tersebut.

\section{Daftar Pustaka}

Hadiwinata, Bob Sugeng. Demokrasi di Indonesia. Yogyakarta: Graha Ilmu, 2010.

Marzuki, Suparman. Politik Hukum: Hak Asasi Manusia. Jakarta: Penerbit Erlangga, 2014.

MD, Moh. Mahfud. Demokrasi dan Konstitusi di Indonesia: Studi Tentang Interaksi Politik dan Kehidupan Ketatanegaran. Jakarta: PT Rineka Cipta, 2003.

-------. Politik Hukum di Indonesia. Jakarta: PT Raja Grafindo Persada, 2012.

http://hilalfarisy.wordpress.com/2012/03/21/sejarah-

perkembangan-demokrasi-di-indonesia/ diakses 6 Maret 2014 http://tifiacerdikia.wordpress.com/lecture/lecture-1/ilmu-

kewarganegaraan/perkembangan-demokrasi-di-indonesia, diakses 6 Maret 2014 